\title{
Teaching Statics Using Agile Methodologies
}

\section{Dr. Anna K.T. Howard, North Carolina State University}

Anna Howard is a Teaching Associate Professor at NC State University in Mechanical and Aerospace Engineering where she has led the course redesign effort for Engineering Statics. She received her Ph.D. from the Rotorcraft Center of Excellence at Penn State University in 2001. 


\title{
Teaching Statics Using Agile Methodologies
}

\begin{abstract}
Statics in the Mechanical and Aerospace Engineering Department at North Carolina State University is taught as a flipped class, a format which works well for the majority but not the totality of students. Agile methodologies such as Scrum have shown good results for improving time management and communication in the workplace. A small pilot class (10 students) was taught using agile methods with the goals of teaching students to work effectively in teams, to manage their time effectively, and to take ownership of their learning. The first two midterms for students in the pilot section were lower than those in the flipped sections but not outside of the standard deviation of the flipped sections. These early grades and student surveys led to restructuring the in-class activities for the pilot class to be more like the flipped class. Future work will need to focus on better training for the students and the professors. Students enjoyed the Scrum class more than they did the less innovative second half of the semester. Overall, this small pilot showed some promise as a way of teaching mechanical engineering with greater student ownership of learning. Agile methodologies hold considerable promise especially for higher-level classes such as mechanical senior design.
\end{abstract}

\section{Introduction: Student Engagement vs Student Ownership}

In 1987 Chickering and Gamson published their famous "Seven Principles for Good Practice" which codified what many good teachers have always known: a good teacher must engage the students in their own learning [1]. Education research has made great strides towards encouraging greater interaction between faculty and students in the last 15-20 years, a period that has coincided with a technological revolution allowing high quality materials to be available for students at any moment. Everything from high-definition video to clickers to online quizzing gives students just-in-time access to whatever they need to learn at the moment [2-5].

Engineering Statics at NC State University in the Mechanical and Aerospace Engineering Department is taught as a flipped class to maximize student engagement. Traditional lectures are replaced by short videos of content explication and example problems for students to absorb outside of class so that in-class time can be spent with students working together in teams to solve problems while TAs and instructors are available to help [6-7]. Flipped classes show increases in both learning and engagement by the students during class, but a flipped class is still a top-down system which tells the student exactly what to do and when. Opportunities for students to manage their own learning are somewhat limited.

Mastery learning can be one way to address this lack of student ownership. Some faculty have tried allowing students to resubmit homework as often as required until the students succeed or to provide retakes for exams [8-9]. Another idea is to take a cue from recent developments in product development. Tracking progress in product development is an ongoing challenge for any company which mimics in some ways the progress in student learning of a body of material.

The computer science realm has led the charge for agile methods based on iterative stages of 
developing software [10]. The most basic idea of a Gantt chart from 1917 of what is required and in what order developments should occur is crucial, but these charts can be improved on by allowing users to adjust timelines on the fly [11]. Many so-called DevOp tools have been developed over the last decade to facilitate tracking of software development, bug tracking, and entire life-cycles for software [12]. The idea is to adapt, iterate, and prioritize working quickly and deftly rather than following a plan [13]. Gradually the success of these tools has encouraged other product development realms to adopt similar strategies. Educators are also beginning to look into agile methods since product development and student learning have many parallels.

\section{Scrum}

Scrum is one example of an agile framework used to focus a team on what needs to be done and improve communication between team members [13]. Originally named for the rugby play where two teams, arms locked together, hunch around the ball to struggle together to get the ball back, a Scrum team uses short sprints, usually two weeks, to develop a working, quality-tested prototype at the end of the two weeks [14-15]. The guiding principles are transparency, inspection, and adaptation.

The Scrum team includes a product owner, the development team, and a Scrum master. The product owner creates a set of requirements, the development team decides how to tackle achieving those requirements (in increments of “done”), and the Scrum master helps keep everyone on task [15]. Scrum requires four formal events during each sprint: planning, the daily Scrum, the review, and the retrospective. A Scrum board is used to track the backlog (lists of requirements not yet met with their priority ranking), the current tasks in the sprint, and the bugs which have been found [16].

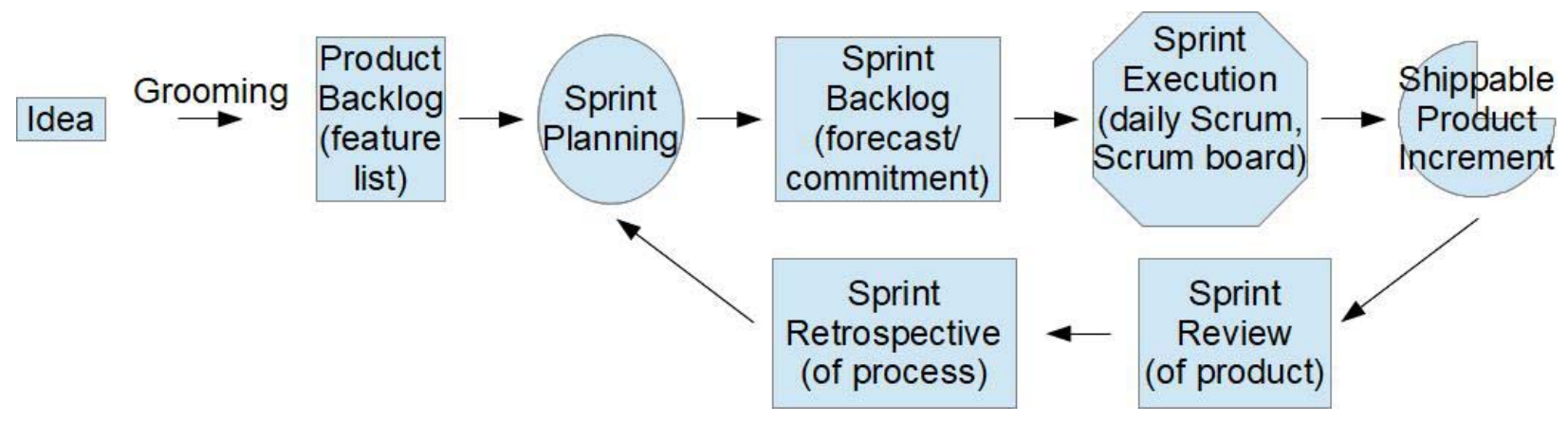

The basic steps in the Scrum framework are shown in the figure above. First an idea is groomed into a set of features. The sprint planning takes that list of features and decides based on priority what the first thing to do is. A subset of the total product backlog is agreed to by the Scrum team and makes up the sprint backlog. The sprint backlog is agreed on by the team as a commitment to what they'll accomplish during the sprint with an emphasis that this is flexible as problems arise. During the sprint, the team meets every day for a five-minute, stand-up meeting where team members address their accomplishments, their plans for the next day, and any issues that have arisen. At the end of the sprint a tested, functional product is available: this product increment will not have all the features of the product backlog but should include working versions of the features included in the sprint backlog. The sprint review addresses the functionality of the product while the sprint retrospective addresses the process. The next sprint begins with sprint 
planning to address the next set of features to be tackled.

\section{Scrum for Education}

Educators in computer science have begun implementing these methods and tools in their classrooms in part at the behest of their industries who would like to hire students already trained [17]. Other educators have noticed that the flexibility in response to complicated objectives has a lot in common with many classrooms beyond computer science. EduScrum was developed in the Netherlands and showed favorable results with scrum as a pedagogical technique in middle school [18]. The Product Owner is replaced by the teacher who decides what needs to be learned and to what level. The teacher defines certain acceptance criteria which can be test scores or scopes of projects. The student teams (generally 4 or 5 students) are self-organized and decide how to achieve the learning goals [19].

The Scrum board or the eduScrum Flip is the transparency in the agile system. Product features or learning objectives are adopted in the sprint planning. These move from a backlog column to a busy column when the team is working on that task, and then into a done column when that task is accomplished [20]. Software, such as Trello and the Atlassian Toolset, has been developed to help teams collaborate on development projects which are inherently complex and evolving over time [21-22].

\section{Applying Scrum to Engineering}

Scrum offers an educator benefits: learning objectives are brought into focus for the students, teamwork and time management are emphasized, and working like a professional is required. Students who take responsibility for their own learning do better, and agile methodologies would put the students in charge of learning the material [23]. The instructor becomes a facilitator, the manager of the materials.

Outside of computer science and software engineering, Scrum has been used in teaching capstone design in several universities [17, 24]. The University Rovira i Virgili has also used Scrum methods to handle homework for engineering mechanics [25]. Beyond these this author is not aware of any application of Scrum principles to teach mechanical engineering.

\section{This Project}

In Spring 2017 students were solicited to apply for a pilot class using Scrum. The number of students was kept very limited because we wanted to make sure that no harm came to the students; keeping the number of students limited meant that the instructor could provide one-onone help to each student beyond what would be available in a lecture or flipped class.

Students were given a brief description (included as an appendix here). Ten students were selected to fill out two teams of five students. The students included eight men and two women, nine sophomores and one junior, with intended careers of Aerospace Engineering (2), Applied Mathematics (1), Computer Engineering (1), Mechanical Engineering (4), and Nuclear Engineering (2). Neither student grade-point averages nor prerequisite grades were available as this pilot was intended as a proof-of-concept learning opportunity and did not include student advisors or Registration and Records personnel. 
The first meeting for the class arranged the students into groups which were based on convenient meeting times for out-of-class work. The students decided to keep the requirement of turning in homework and quizzes: deadlines were extended to be at the midterm exams. The Jira Suite from Atlassian was selected to use for the Scrum board; learning objectives for the entire class were selected by the instructor and posted in Jira [9, 10]. Student success was measured by having the students take the same midterms and final exams as the flipped classes: in eduScrum terms, this is setting the acceptable level of "done” $[13,14]$. For example, one learning objective in Statics is to "Recognize and classify a force expressed as a magnitude along a line, and correctly express that force in Cartesian form for both two- and three-dimensional forces at least 95\% of the time." Each task/learning objective is marked as To Do, Busy, or Done.

Students were given total access to all the materials available for the flipped class including (but not limited to) short concept videos for lecture replacement, example problems with accompanying videos, html class notes, the textbook, and the course pack which included skeleton notes for the text readings as well as the PowerPoint slides used during the flipped class. Students also had access to several message boards (forums) in which to ask questions. Student teams were encouraged to explore the topic at their own pace to reach the specified learning objectives, working together as much as they desired.

The fourteen-week semester for Statics is divided in the flipped class by the three midterms. While this was not quite a uniform, two-week sprint, the midterms approximated that chunk of material that would have been selected at a sprint planning meeting. At the end of each sprint, Scrum teams were allowed to vote to maintain the team or to be reshuffled within the section of students.

Once the class was set up, the teams met with the instructor for a stand-up; these meetings usually took ten minutes during which each student took turns answering the three stand-up questions:

1) What did I do?

2) What am I going to do next?

3) And what issues did I encounter that kept me from making more progress?

The scrum team was tasked with determining how they wanted to learn. Between the beginning of the semester and the first exam, these stand-up meetings were three times per week. Between the first two midterms, the stand-up meetings were reduced to twice a week.

After each exam the scrum team met with the instructor to host a retrospective to evaluate the process, what went well and what improvements were needed for the next sprint.

\section{Results}

Student groups chose to complete homeworks and quizzes as did their in-class colleagues. Students were presumably more comfortable with the familiar trappings of a "normal” class. Students met twice a week outside of class with the expectation that no one would miss both meetings. The Jira software was jettisoned quickly in favor of a spreadsheet in Google docs. Students reported seeing little use in learning new software to communicate with each other and with the instructor since that functionality was already captured in Google docs and GroupMe, 
online environments where the students already felt comfortable. During each stand-up, students took turns updating each other and the professor on progress attained toward each of the learning objectives.

As the instructor I really enjoyed the stand-up meetings. I felt that I got to know the students considerably more than in a lecture or even in a flipped class. I could see who was working hard, who was stuck on only one small thing, and who needed more guidance with just about everything. What I did not see was students designing their own way to learn. I had hoped that students knew how they learned best and would take advantage of the freedom available in this agile class to adjust when things were due and what learning objects were best suited to their style. While this was a very small pilot, in my opinion students were new to engineering and fell back on waiting to be told what to do as soon as the material was unfamiliar.

The student results were within range of the standard deviations of the students in the flipped class though lower (see Table 1).

Table 1: Homework Averages

\begin{tabular}{|l|c|c|c|c|c|c|c|c|c|}
\hline \multicolumn{1}{|l}{ Homework Averages, All Students } \\
\hline Pilot & 10 & 87.1 & 17 & 68.5 & 35 & 72.9 & 39 & 74.6 & 18 \\
\hline Flipped & 152 & 83.7 & 24 & 73 & 29 & 77.1 & 31 & 77.9 & 18 \\
\hline Exam 1 & stdev & $\begin{array}{c}\text { Before } \\
\text { Exam 2 }\end{array}$ & stdev & $\begin{array}{c}\text { Before } \\
\text { Exam 3 }\end{array}$ & stdev & $\begin{array}{c}\text { Homework } \\
\text { Overall }\end{array}$ & stdev \\
\hline Homework Averages, Only Students Who Took the Final Exam \\
\hline & N & $\begin{array}{c}\text { Before } \\
\text { Exam 1 }\end{array}$ & stdev & $\begin{array}{c}\text { Before } \\
\text { Exam 2 }\end{array}$ & stdev & $\begin{array}{c}\text { Before } \\
\text { Exam 3 }\end{array}$ & stdev & $\begin{array}{c}\text { Homework } \\
\text { Overall }\end{array}$ & stdev \\
\hline Pilot & 8 & 88.2 & 17 & 69.3 & 34 & 72.9 & 39 & 75 & 17 \\
\hline Flipped & 146 & 85.4 & 22 & 75.1 & 27 & 79.3 & 29 & 80.1 & 14 \\
\hline
\end{tabular}

Table 2: Exam Averages

\begin{tabular}{|c|c|c|c|c|c|c|c|c|c|c|c|}
\hline \multicolumn{10}{|c|}{ Exam Averages, All Students } & \multirow[b]{2}{*}{ Overall } & \multirow[b]{2}{*}{ stdev } \\
\hline & $\mathrm{N}$ & $\begin{array}{c}\text { Exam } \\
1\end{array}$ & stdev & $\begin{array}{c}\text { Exam } \\
2\end{array}$ & stdev & $\begin{array}{c}\text { Exam } \\
3\end{array}$ & stdev & $\begin{array}{l}\text { Final } \\
\text { Exam }\end{array}$ & stdev & & \\
\hline Pilot & 10 & 67.1 & 16 & 60.6 & 18 & 64.5 & 37 & 55.5 & 32 & 73.6 & 10 \\
\hline Flipped & 152 & 77 & 15 & 63.2 & 21 & 73.3 & 24 & 65.1 & 23 & 74.7 & 14 \\
\hline \multicolumn{10}{|c|}{ Exam Averages, Only Students Who Took the Final Exam } & & \\
\hline & $\mathrm{N}$ & $\begin{array}{c}\text { Exam } \\
1 \\
\end{array}$ & stdev & $\begin{array}{c}\text { Exam } \\
2 \\
\end{array}$ & stdev & $\begin{array}{c}\text { Exam } \\
3 \\
\end{array}$ & stdev & $\begin{array}{l}\text { Final } \\
\text { Exam }\end{array}$ & stdev & Overall & stdev \\
\hline Pilot & 8 & 73.2 & 9 & 67.9 & 9 & 80.6 & 17 & 69.3 & 16 & 76.5 & 9 \\
\hline Flipped & 146 & 78.5 & 13 & 66.8 & 16 & 78 & 16 & 70.4 & 14 & 76.9 & 10 \\
\hline
\end{tabular}


Students in the scrum section were surveyed midway through the semester and at the end of the semester. (Surveys were not administered to flipped class students.) Student surveys showed quite positive feelings about the course. No student indicated a preference to change team members. The survey reports are shown with the number of students who chose each option.

1. Rate the amount of work you did mid-semester: 0 Almost none 1 What was assigned 9 More than just what was assigned semester end: 0 Almost none 5 What was assigned 3 More than just what was assigned

2. Rate the level of your involvement in the activities of this course.
mid-semester: 0 Very uninvolved
4 Somewhat involved
6 Enthusiastically involved
semester end: 0 Very uninvolved
3 Somewhat involved
5 Enthusiastically involved

3. How much practical knowledge have you gained from this course?
mid-semester: 9 A great deal
1 Some practical knowledge 0 None
semester end: 4 A great deal
4 Some practical knowledge 0 None

Table 3: Survey Results Continued

\begin{tabular}{|l|c|c|c|c|c|}
\hline $\begin{array}{l}\text { Students agreeing with these statements } \\
\text { at mid-semester and semester end: }\end{array}$ & $\begin{array}{c}\text { Strongly } \\
\text { Agree }\end{array}$ & Agree & Neutral & Disagree & $\begin{array}{c}\text { Strongly } \\
\text { Disagree }\end{array}$ \\
\hline The course objectives were clear & 4 & 6 & & & \\
\hline The course procedures and assignments & 4 & 5 & 1 & & \\
support course objectives & 3 & 4 & 1 & & \\
\hline The amount of reading you were asked & 3 & 7 & & & \\
to do was appropriate & 2 & 6 & & & \\
\hline The amount of writing or other class & 4 & 4 & 2 & & \\
work you were asked to do was enough & 2 & 5 & & & \\
\hline
\end{tabular}

4. What overall rating would you give the course?

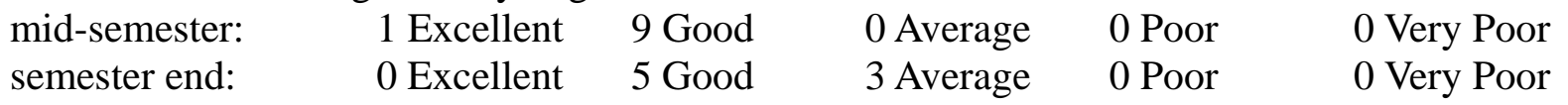

After the second exam where students in the pilot Scrum section continued to have lower exam averages than in the flipped sections, students were given the option to move from the pilot section to the flipped section. None of the students chose to change sections. Students did however choose to change the format of the in-class portion. The stand-ups were discarded in favor of following a teacher-led problem sessions. The pilot class resembled the flipped class very much for the second half of the semester with quizzes at the beginning of class to assess preparation levels and problems for the students to work in groups during the in-class hour. The pilot was different from the flipped class even in the second half in that the student groups were not instructor-assigned nor changed up; additionally clickers were not used in the pilot group. 
Students in the pilot group were allowed to work together on the computer-graded homework whereas the students in the flipped section were discouraged from doing so. In both sections onpaper homework was collected and graded as individual effort.

\section{Discussion}

The proof of concept of using Scrum to teach mechanical engineering was borne out with the student exam results though the benefits of Scrum were not fully realized with student-led ownership. It may be that more training at the beginning of the semester, moving more classes to this format, or waiting until the students are farther along in engineering would allow students to take more control of their own learning. In future classes, the first module should be on the method rather than having students figure it out as they go along. Though students in the Scrum section had lower test averages during exams 1 and 2, when they opted not to continue the Scrum stand-ups during the second half of the semester their test grades did not show any improvement. If the grades for the pilot class had increased relative to the flipped class grades for the final midterm and final, we would have concluded that the flipped format was preferable for the students over the scrum format. Since we did not see that increase in grades, we are inclined to believe that the scrum format was as effective as the flipped format, but the very small numbers of students in the pilot class limits our ability to show this statistically.

Student opinions of the class were actually better during the period when the Scrum stand-ups were used than after they were abandoned. The new method of organizing class led to greater enthusiasm for teacher and students. The scrum format allowed for a new way to interact with students on a daily basis. Putting the tasks together led to greater focus on what the learning objectives were for each and every day - and on what individual metrics could be used by the students and by the exams to determine whether those learning objectives were met.

\section{Future Work}

Offering a Scrum section for Statics should be undertaken again before the method is rolled out to further classes. Clearly students will need more training on how to maximize their learning when they're in charge of what to do and when. With that said, the data gathered here gives us confidence that Scrum has potential to increase student ownership of their learning without negatively affecting how much they learned in the process.

\section{References}

[1] Chickering, Arthur W., and Zelda F. Gamson. "Seven Principles for Good Practice in Undergraduate Education.” From The American Association for Higher Education Bulletin , March 1987." (2011).

[2] Ponton, M. (2002). "Motivating Students by Building SelfEfficacy." J. Prof. Issues Eng. Educ. Pract. , 10.1061/ (ASCE)10523928 (2002)128:2(54), 5457.

[3] Dabbagh, N. (2007) “The online learner: characteristics and pedagogical implications”, Contemporary Issues in Technology and Teacher Education , vol. 7, no. 3, pp. 217-226.

[4] Kuh, George D. "Assessing what really matters to student learning inside the national survey of student engagement." Change: The Magazine of Higher Learning, 33.3 (2001): 1017.

[5] Howard, A. K. T., “Enhancing Student Engagement in Engineering Statics with Online Tools,” ASME 2010 International Mechanical Engineering Congress \& Exposition, Vancouver, BC, Canada, November 1218, 2010.

[6] EDUCAUSE. (February 2012). 7 things you should know about flipped classrooms. Online at: http://net.educause.edu/ir/library/pdf/ELI7081.pdf 
[7] Bishop, Jacob Lowell, and Matthew A. Verleger. "The flipped classroom: A survey of the research." ASEE National Conference Proceedings, Atlanta, GA. 2013.

[8] Moore, Jacob, and J. Ranalli. “A Mastery Learning Approach to Engineering Homework Assignments.” ASEE Annual Conference and Exposition, Conference Proceedings, vol. 122, 2015.

[9] Sangelkar, Shraddha, et al. Mastery Learning in Engineering: A Case Study in Statics. 2014, p. 24.887.124.887.19. peer.asee.org, https://peer.asee.org/mastery-learning-in-engineering-a-case-study-in-statics.

[10] What Is Scrum? An Agile Framework for Completing Complex Projects - Scrum Alliance. https://www.scrumalliance.org/why-scrum. Accessed 6 Feb. 2018.

[11] Clark, Wallace, et al. The Gantt Chart, a Working Tool of Management. New York, The Ronald press company, 1922. Internet Archive, http://archive.org/details/cu31924004570853.

[12] Agile Methodology. http://agilemethodology.org/. Accessed 6 Feb. 2018.

[13] Manifesto for Agile Software Development. http://agilemanifesto.org/. Accessed 6 Feb. 2018.

[14] Takeushi, Hirotaka, and Ikujiro Nonaka. “The New New Product Development Game.” Harvard Business Review, 1986.

[15] Schwaber, Ken, and Jeff Sutherland. "The Definitive Guide to Scrum: The Rules of the Game.” The Scrum Guide ${ }^{\mathrm{TM}}$, Nov. 2017, http://www.scrumguides.org/docs/scrumguide/v2017/2017-Scrum-GuideUS.pdf\#zoom=100.

[16] Rubin, Kenneth S. Essential Scrum: A Practical Guide to the Most Popular Agile Process. Addison-Wesley Professional, 2012.

[17] Pedrosa, K., Tubbesing, R., Stansbury, R., and Liu, J. "Fostering Agile Methodologies In Crossdisciplinary Capstone Design Course Through Process Management Tools”, Proceedings of the 2016 ASEESE Annual Conference, ASEE-SE (2016).

[18] de Jager, T. W. "Using eduScrum to introduce projectlike features in Dutch secondary Computer Science Education." (2015).

[19] Delhij, Arno, et al. "The EduScrum Guide.” The eduScrum Guide: The Rules of the Game, Sept. 2015, http://eduscrum.nl/file/CKFiles/The_eduScrum_Guide_EN_1.2(1).pdf.

[20] Maruping, Likoebe M., Viswanath Venkatesh, and Ritu Agarwal. "A control theory perspective on agile methodology use and changing user requirements." Information Systems Research, 20.3 (2009): 377399.

[21] Trello. https://trello.com/ . Web. 29 Mar. 2016.

[22] Atlassian. https://www.atlassian.com/ . Web. 29 Mar. 2016.

[23] Haron, Habibah @. Norehan Hj., et al. “Does Motivation Affect Students’ Understanding and Performance in Engineering Statics?” Procedia - Social and Behavioral Sciences, vol. 56, Oct. 2012, pp. 191-203. ScienceDirect, doi:10.1016/j.sbspro.2012.09.646.

[24] Edin Grimheden, Martin. “Can Agile Methods Enhance Mechatronics Design Education?” Mechatronics, vol. 23, no. 8, Dec. 2013, pp. 967-73. ScienceDirect, doi:10.1016/j.mechatronics.2013.01.003.

[25] Pons, Cristina Urbina, and Sergio Sanchez Lopez. "Assessment Activities in Mechanics: How Many of Them Are Enough?” International Conference, New Perspectives in Science Education, 6th ed., 2017. 


\section{Appendix: Invitation for Students to Apply for Pilot Course}

I am teaching a highly experimental form of Engineering Statics for this spring. Section 1 will be limited to only 15 people. Admission will be by application to me. Sections 2 and 3 are my regular flipped sections.

What's the idea here?

- Software development has spawned new ways of organizing productivity. These new processes are called agile methodologies. Scrum is one such agile methodology.

- Rather than describe how you would build the software to solve a problem, agile methodologies clearly state the goals and let the teams come up with how they want to meet the goals.

- Deliveries of working products are made at the end of each sprint period (usually two-four weeks). Though the working product may not be completely functional, it needs to be understood, tested, and delivered at the end of each sprint.

- Faculty around the globe are starting to look at these methods for teaching. Instead of telling students what they have to do, perhaps we should be telling them what they need to learn. Then we can equip them with options for meeting the objectives.

- These methods allow the student-teacher relationship to evolve from what some have called the "sage on the stage" to being the "guide on the side." The flipped classroom is one step in this direction where students are an active participant in their learning. These methods would be another step in that direction where the student becomes the leader in figuring out how to learn. My job becomes two-fold: I need to specify exactly what it is you need to know, and I need to make sure you have everything you need to succeed.

- Students will be grouped into teams of 5. Teams will meet with me for a 5-7-minute stand up meeting during which you will each talk. Each student addresses what he has done, what he has left to do, and what is standing in the way of meeting those goals.

- There will not be any lecture. You will have access online to all the course materials to use as you see fit. These materials have been shown to be sufficient for dedicated students to succeed at the class. These include:

- review materials on trigonometry and matrix algebra

- more than 75 short lecture videos (6 minutes on average)

- more than 200 example videos (8 minutes on average)

- html notes (more than 10,000 words plus images)

- the textbook and the accompanying skeleton notes to help you read the book

- the slides that I use in the flipped course and 50-minute videos of the students in those sections working the problems so you can hear what I tell them

- 50-minute lectures back from when I last did this by lecture in 2010

- daily online checkpoint quizzes (5-question multiple choice questions that reinforce the principles from that day's class)

- daily online homework quizzes for practice

- and daily on-paper homework problems which bring together all that you learned

- Students in this section will take the same tests in Moodle as students in every other section.

- Students will be expected to fill out a daily task board and answer midterm and end-of-semester surveys.

Why is this experimental?

- As far as I can tell, this has never been tried for a Statics class.

- Given that my role is to get out of the way, I do not know how teams will decide to use the materials available. I also do not know how much I will need to help.

- I cannot at this time tell you what your grade will be based on for certain. Each midterm will be worth $14 \%$ of your semester grade. The final will be $23 \%$. The team functioning will be worth $10 \%$; we will work together to specify how this will be managed. This leaves $25 \%$ of your semester grade. Teams will decide whether to commit to quizzes or homework or apply this percentage to the other tests and teamwork.

How do I apply?

- Students must be available to meet with me on MWF for 10 minutes between 8:30 and 9:20.

- Students must be available to meet with their teams as often as needed other than those times to ensure the team success in preparing for the exams.

- Students must be willing to work with me to make sure this succeeds including filling out surveys and providing feedback about their team functioning.

- Students must be willing to learn about teamwork and leadership alongside Statics.

- If you are interested in taking section 1, email me at [redacted]. Include at least 250 words describing your desire to take this section. (Have some reason other than you like the time of day, please.)

I am very excited about this opportunity. I'm looking for 15 students who are also interested in focusing on what they need to learn rather than what homework is due tomorrow. 